\title{
Mediterranean landscape change during \\ the Holocene: synthesis, comparison and regional trends in population, land cover and climate
}

Roberts, C Neil

http://hdl.handle.net/10026.1/13132

$10.1177 / 0959683619826697$

Holocene

SAGE Publications

All content in PEARL is protected by copyright law. Author manuscripts are made available in accordance with publisher policies. Please cite only the published version using the details provided on the item record or document. In the absence of an open licence (e.g. Creative Commons), permissions for further reuse of content should be sought from the publisher or author. 
The Holocene, 2019

Mediterranean landscape change during the Holocene: synthesis, comparison and regional trends in population, land cover and climate

Roberts, N. ${ }^{1}$, Woodbridge, J. ${ }^{1}$, Palmisano, A. ${ }^{2}$, Bevan, A. ${ }^{2}$, Fyfe, R. ${ }^{1}$, and Shennan, $\mathrm{S}^{2}$.

1. School of Geography, Earth and Environmental Sciences, University of Plymouth, Plymouth, UK

2. Institute of Archaeology, University College London, London, UK

\section{Abstract}

This synthesis paper offers a comparative perspective on how seven different Mediterranean regions, from Iberia and Morocco to the Levant, have been transformed by human and natural agencies during the last ten millennia. It draws on a range of sources of data notably, 1$)$ archaeological site surveys $(n=32 k)$ and ${ }^{14} \mathrm{C}$ dates $(n=12 k)$ as proxies for long-term population change, 2) pollen records as a proxy for past vegetation and land cover ( $n=157)$, and 3 ) proxies, such as stable isotopes, from lake, cave and marine records as indicators of hydro-climate $(n=47)$. Where possible, these data sets have been made spatially and temporally congruent in order to examine relationships between them statistically and graphically. Data have been aggregated or averaged for each region/subregion and put into 200-year time windows. Archaeo-demographic data show a clear increase at the start of Neolithic farming, followed by a series of regionally-asynchronous fluctuations in population, prior to a pan-Mediterranean Roman settlement maximum. Pollen data indicate a Late Holocene decline in \%Arboreal Pollen in those regions that were initially well-wooded, but not in drier regions of the southern/eastern Mediterranean. Overall, the clearest palynological proxy for human land cover change is provided by the OJCV (tree crop) index. The cultivation of these trees in the eastern Mediterranean after $6500 \mathrm{Cal}$ yr BP may have been an adaptive response to mid-Holocene climatic desiccation. These anthropogenic pollen indicators correlate more closely with trends in population than with regional hydro-climatic z-scores, implying that they reflect primarily human activities. During the mid-Holocene, most Mediterranean landscapes were transformed by a combination of climate and rural land use, but after $\sim 3500$ Cal yr BP, human actions became increasingly dominant in determining land cover. During the last 1500 years the dominant landscape trajectory in the eastern Mediterranean was markedly different to that in the central/western Mediterranean. 


\section{Introduction}

The lands surrounding the Mediterranean Sea form the geographical cradle for several past societies with global cultural impacts. These lands are the product of a distinctive climate and natural environment that have been transformed by human agency over many millennia (Horden and Purcell, 2000; Abulafia, 2011; Broodbank, 2013). There has been longstanding debate about the relative roles of human and natural factors in moulding Mediterranean landscape ecologies (e.g. Pons and Quézel, 1998; Grove and Rackham, 2001; Barker, 2005; Butzer, 2005; Walsh, 2014; see Bevan et al. (this volume) for further discussion). Population dynamics are recognized to have been one of the key drivers of Mediterranean landscape transformation during the Holocene (Bintliff and Sbonias, 1999). Consequently, we can ask what the impact was of changes in human demography upon rural land-use intensity, how far this pressure drove the transformation of the Mediterranean from nature-dominated to human-dominated, and how this varied regionally.

Three different potential causal relationships that have previously been hypothesised are that (1) climate change directly determined Mediterranean vegetation and land cover composition (e.g. Jalut et al., 2009; Di Rita et al., 2018), (2) climate change impacted human society and populations (e.g. Rosen, 2007; Kaniewski and van Campo, 2017), (3) human populations caused changes in land cover, via forest clearance, farming, etc (e.g. Hughes 2014). If (2) can be demonstrated, then climate change could potentially also have had an indirect effect on land cover via human actions (3). In this study, we test these causal linkages by examining statistical and graphical relationships between relevant proxy indicators in different regions of the Mediterranean. A synthesis combining data from the natural sciences and the humanities has the potential to provide the evidence base for the sustainable future use of the Mediterranean's iconic landscapes, which are now threatened through commercial forestry, tourist development, wildfire and over-use of water resources.

\section{Materials and methods}

Fossil pollen is the most widely distributed source of data for reconstructing Holocene vegetation and land cover, although data are often lacking for dryland regions such as parts of North Africa. The availability of archived pollen data in recent years has made it possible to synthesise long-term patterns of Mediterranean land cover change (Collins et al., 2012; 
Fyfe et al., 2018; Woodbridge et al., 2018). Long-term changes in human population can be derived from results of archaeological field investigations, specifically from regional site surveys and by using radiocarbon $\left({ }^{14} \mathrm{C}\right)$ dates from excavated sites. For changes in hydroclimate, there is a wide array of different proxy sources available from the Mediterranean (Finné et al., 2011), notably from cave and lake sequences. Pollen data have also been used to reconstruct Holocene climate changes in the Mediterranean (e.g. Guiot and Kaniewski, 2015), but we have avoided doing so here because of the risk of circular reasoning, as the same source of information cannot provide both cause (climate) and consequence (land cover).

The assessment of human and natural factors requires datasets that are commensurate in both temporal and spatial scales. Most of the pollen and archaeological data used here derive from seven geographical case-study areas, allowing direct comparison between datasets without the need for correlation over long distances. Where possible, this is also the case for evidence of past hydro-climate (Finné et al., 2019). Study regions were chosen partly to ensure adequate data coverage for both pollen and archaeology, and partly to provide good geographical coverage over the Mediterranean basin as a whole. The case study regions (table 1; Fig. 1) extend from the Levant in the east to Iberia and Morocco in the west, which is also the broad direction in which many cultural and technological developments have spread during the Holocene (Broodbank, 2009; Bevan, 2014). The geographical distribution of these study regions from the eastern to the western Mediterranean offers the possibility of identifying inter-regional contrasts in the timing and magnitude of socio-ecological change; for example, linked to the spread of Neolithic farming economies (Hofmanovà, 2016; Shennan, 2018).

The data sets and time spans for individual case study regions are summarised in table 1 , four of which have been sub-divided to create fourteen regions/sub-regions in total. Proxies for population, land cover and climate have been put on a common timescale after 10,000 Cal yr BP (11,000 BP for the Levant), which, in turn, allows statistical relationships between them to be calculated.

While we have attempted to achieve spatial and temporal congruence between different data sets, in practice this has not always been possible. For example, there are insufficient systematic archaeological site survey data for eastern Iberia or Morocco to allow analysis of trends in settlement numbers or areas, so instead only summed ${ }^{14} \mathrm{C}$ probabilities are used to reconstruct past population for these regions. Equally, not all approaches can be applied over the full timespan of the Holocene. For archaeology, reconstructed population trends end in Medieval times, and in some cases they stop well before this. This means that in 
regions such as Iberia and Morocco, the main period of land cover transformation recorded in pollen data occurred after the end of the archaeologically-inferred population reconstruction. No single analytical dataset therefore provides a "complete" record of land cover or demographic change, which means that multiple data sets have to be used in combination in order to obtain a full picture. Notwithstanding this, it is possible to make direct comparison between different data sources and regions over extended periods of Holocene time, as set out below.

Archaeology. Long-term changes in human population have been inferred from two sources: firstly, the temporal distribution of ${ }^{14} \mathrm{C}$ dates from archaeological excavations (e.g. Shennan et al., 2013; Drake et al., 2017), and secondly, regional settlement numbers and areas from systematic regional site surveys (Palmisano et al., 2017). Summed Probability Distributions (SPDs) of calibrated ${ }^{14} \mathrm{C}$ dates are available for all case study areas, but after 6000 Cal yr BP in Anatolia they are too few to be reliable (table 1). In most cases these SPDs provide meaningful information for prehistory and proto-history (i.e. prior to $\sim 2500 \mathrm{Cal}$ yr BP). Only Southern France has a ${ }^{14} \mathrm{C}$ date SPD record that extends into historic times (until $700 \mathrm{Cal}$ yr BP). On the other hand, settlement data from archaeological surveys can extend through until $1000 \mathrm{Cal}$ yr BP or more recently. In order to address issues related to the temporal uncertainty of occupation periods, we adopted a combination of "aoristic" and Monte Carlo methods, which model either the probability of existence of a given site or site intensity within each time-step (see Crema 2012). Details of these methods are set out in Palmisano et al. (2017). The resulting demographic proxies (site counts, aggregated estimated settlement size, aoristic sum and randomised site durations) have been binned into 200-year time slices for comparison with pollen sequences.

Pollen. Most of the data used here derive from the European Pollen Database (EPD; Leydet, 2007-2018), supplemented by additional pollen sites for individual case study regions. Reconstruction of land cover change has resulted from the transformation of multiple pollen records for each case study region, as well as at a pan-Mediterranean scale (described by Fyfe et al., 2018 and Woodbridge et al. 2018). For comparison with archaeodemographic and climate data, pollen records have been transformed via a series of indices taken from the established literature (e.g. Mazier et al., 2006; Mercuri et al., 2013, and this volume) and described in more detail below. Unlike the archaeo-demographic data, pollen data cover the whole Holocene, up to and including modern times. One of the main limitations of the pollen data is the low number of sites represented in some time intervals in some regions. Ideally there should be at least $\sim 10$ samples for all time intervals to obtain a representative picture, but this is not always the case (e.g. within the Balearics and 
northeast lberia during the early Holocene). When there are fewer sites represented in a time window, each record has a greater impact on the overall pattern.

Climate. Finné et al. (this volume) have synthesised Mediterranean hydro-climate datasets into the same 200-year time windows used to reconstruct past land cover and population. This synthesis is based on 47 lake, cave and marine proxy records within the Mediterranean and does not draw on pollen data, for reasons explained earlier. Individual proxy data (e.g. stable isotopes) have been put on a common timescale and transformed into z-scores to allow direct comparisons between records. It should be noted that the 200-year long time windows used here make it difficult to identify short-lived, sometimes abrupt, climate events, such as those at 8.2, 4.2 and 3.2 ka BP (Flohr et al., 2016; Kaniewski and van Campo, 2017).

Six different regions have been identified based on numerical and spatial analyses of zscores of individual climate proxies (e.g. $\delta^{18} \mathrm{O}$ ): southern lberia and Maghreb, northern Iberia, Italy, the Balkans, Turkey, and the Levant, and the overall hydro-climate history of each region reconstructed (see Finné et al., 2019). In addition, non-metric multidimensional scaling (NMDS) has been applied to 18 long, continuous climate z-score records that span the majority of the Holocene. Most of the identified climate regions overlap geographically with the study areas used for archaeo-demographic and land cover reconstruction, which in turn allows direct comparison between them. However, there are insufficient nonpalynological proxy-climate data available from southern France to permit a regional hydroclimate reconstruction, while in eastern Iberia and the Balearics, there is poor spatial congruence between climate records, on the one hand, and pollen/archaeology sites, on the other. Consequently, statistical correlation between climate and pollen-based or archaeological variables has not been attempted for either Spain or France. It should also be noted that hydro-climate data for Italy span the whole of the peninsula, so that any northsouth contrasts are not captured in the regional mean z-score (c.f. Magny et al., 2013).

\section{Primary results}

Archaeo-demography. The results shown in figures 2 and 3 represent relative population changes rather than absolute numbers of people living in a given area. Comparing regions is therefore meaningful in terms of temporal trajectories rather than quantitative values. Because the two archaeo-demographic data sets (site surveys and ${ }^{14} \mathrm{C}$ date SPDs) are complementary, there is value in looking at them together, notably for those case study regions where both data sets are available. The site-derived proxy indicators (raw count, 
aoristic weight, randomised start of date, estimated total area) and SPD of radiocarbon dates have been normalised on a scale between 0 and 1 in order to make them comparable. For the period prior to $2500 \mathrm{Cal}$ yr BP, there is good overall correspondence between population trends inferred from ${ }^{14} \mathrm{C}$ SPDs and settlement surveys in Southern France, Italy and the Levant (Figure 3), although with regional differences in the strength and nature of the correlation. After $2500 \mathrm{Cal}$ yr BP peak settlement numbers are typically an order of magnitude larger than for earlier times (Figure 2b). Numbers of sites recorded for 2300-1500 Cal yr BP therefore "dwarf" those in earlier time periods. This period, corresponding to Roman republican and imperial hegemony, is the one time interval during the Holocene when there was a synchronous demographic maximum over the whole Mediterranean region. For earlier time periods, population trends appear to have been diachronous between different regions. This was the case for the first Neolithic communities, which emerged at the start of the Holocene in the Levant ( 12,000 Cal yr BP, see Roberts et al., 2018b) and reached mainland Iberia and Morocco by 7500 Cal yr BP (see Broodbank 2013, p.185; Shennan 2018, ch. 5). This cultural horizon, linked to the new Neolithic farming economy, was characterised by a sharp inferred rise in population in all study regions (Figure 2a). In between the initial Neolithic horizon and Classical times, there appear to have been a series of long-term "cycles" of population growth and decline in most regions. This pattern of demographic "boom and bust" is especially clear in ${ }^{14} \mathrm{C}$ date SPD time series. These "cycles" were not synchronous between regions, suggesting that the dynamic behind them may have been primarily internal, although several regions do show demographic decline at or just after the 4.2 ka abrupt climate event (Kaniewski et al. 2008; Meller et al. 2015).

Pollen-inferred land cover. Human-induced land cover change at a pan-Mediterranean scale becomes clearly identifiable from $\sim 3500$ Cal yr BP onwards (i.e. since Bronze Age times). If pan-Mediterranean curves for pollen indicator groups are broken down geographically, it can be seen that some, but not all, trends in past land cover are shared between regions. For example, the pollen record of tree cover shows a decline in \%AP (Arboreal Pollen) from $\sim 5000$ Cal yr BP in the western Mediterranean (Iberia, France, Italy), but not in eastern Mediterranean regions (Figure 4a). In Greece and southern Anatolia, there was no overall decline in tree cover between 9000 and $1600 \mathrm{Cal}$ yr BP, while in the Levant it increased overall during the Holocene. This increase in \%AP took place despite an overall tendency towards drier climatic conditions in the eastern Mediterranean after $\sim 6000$ Cal yr BP (Roberts et al., 2011; Finné et al., 2011, 2019). Tree cover in regions such as Anatolia and the Levant reached a minimum during the Classical period (2300 - 1500 BP) and this was followed by a reduction in culturally-created landscapes and re-wilding during 
post-Classical and Medieval times, up until the 20th century. In fact, pollen data indicate an overall increase in tree cover in many Mediterranean regions during recent centuries, suggesting that the "forest transition" occurred earlier here than it did in northern European countries such as Britain (Mather and Needle, 1998).

One reason for the paradox of tree cover not always declining at times of increasing human populations is that \%AP includes cultivated tree crops such as olive and walnut.

Arboriculture is integral to the traditional Mediterranean rural economy, notably via the triad of cereals, olive and vine, and at times it has led to specialist monocultures for industrialscale production of goods such as olive oil, as it does in parts of south-eastern Spain and southern Italy today. Regional trends in \%OJCV (Olea, Juglans, Castanea, Vitis; figure 4b) show marked differences in the importance of tree crops over space and time. In southern France, for example, pollen data imply that tree crops only became regionally significant in Medieval and post-Medieval times. By contrast, in the Levant, olive has been a major element in the landscape ecology and rural economy since $\sim 6500 \mathrm{Cal}$ yr BP (see Langgut et al., 2019). Not all Olea or Vitis pollen derives from cultivated, as opposed to wild, trees/shrubs. However, the data shown in figure $4 \mathrm{~b}$ suggests that outside the EuMediterranean zone, wild forms have rarely exceeded $\sim 3 \%$ of total pollen whereas cultivated trees can represent $>50 \%$ of pollen at individual sites (Roberts, 2018).

The problem of distinguishing human from natural disturbance is especially acute when using indices such as the Anthropogenic Pollen Index (API) Artemisia, Centaurea, cichorieae and Plantago, cereals, Urtica and Trifolium type, or pastoral indicators (Asteroideae, Cichorioideae, Cirsium-type, Galium-type, Ranunculaceae and Potentilla-type pollen)), which have typically been developed in a temperate European context. Several of the taxa included in these indices, such as Artemisia, were absent from temperate Mesolithic Europe, and their appearance in pollen diagrams from Neolithic times onwards has been interpreted as indicating anthropogenic vegetation disturbance and opening of the forest. In areas such as Morocco and central Anatolia, on the other hand, these "disturbance indicators" are part of natural Mediterranean steppe flora; they should therefore be interpreted with considerable caution in a Mediterranean context. The API and grazing indicators have increased in the last three millennia, probably largely due to human activities, but they were already an integral part of Mediterranean landscape ecology during the mid-Holocene (sensu Walker et al., 2012).

Hydro-climate. The synthesis of Finné et al. (2019) highlights a dominant south/east vs north/west Mediterranean hydro-climatic see-saw during the Holocene. Wetter climatic conditions characterised southern and eastern parts of the Mediterranean prior to $\sim 6000 \mathrm{Cal}$ 
yr BP, including North Africa, the Levant and most of Anatolia; and these wetter conditions extended into Greece, the Balkans and much of Italy during the period from 8500 to 6000 Cal yr BP. After this time, the climate of these regions experienced an oscillating drying trend, which reached a peak of aridity around $3000 \mathrm{Cal}$ yr BP in the eastern Mediterranean and North Africa, although this peak appears to have occurred earlier in Italy ( 4000 Cal yr BP). Southern and eastern parts of the Mediterranean would have been influenced, albeit indirectly, by shifts the extent and strength of the African and Indian monsoon systems. Northern Iberia appears to have been largely decoupled climatically from other Mediterranean regions throughout the Holocene, and was more strongly influenced by North Atlantic forcing (e.g. Bond cycles); this may also have been the case in southern France. There was therefore no single climate trajectory that characterized the whole Mediterranean basin during the last ten millennia. Differences between Mediterranean regions are likely to have been ultimately due to changes in the configuration of ice-sheets, ocean temperatures and circulation, and solar insolation during the course of the Holocene.

\section{Regional analysis}

In the Levant (Palmisano et al. 2019), Neolithic communities began farming very early in the Holocene. ${ }^{14} \mathrm{C}$ SPD data show that population growth started here in Late-Glacial times (Roberts et al., 2018b), and there was a notable demographic "bulge" between 10,600 and 9500 Cal yr BP at the start of the Pre-Pottery Neolithic B (PPNB) period, when a true


the regional vegetation was dominated by grassland and oak-terebinth (Quercus-Pistacia) parkland, with relatively low overall AP\%. There is evidence of an increase, rather than a decline, in tree cover at the same time as the initial population "boom", notably by deciduous oak in the Lake Hula pollen core. This is plausibly explained by an increase in climatic moisture, as recorded at sites such as Soreq and Jeita caves, which would have favoured both early cereal agriculture and also allowed enhanced tree growth (Asouti and Fuller 2012). The initial demographic boom was followed by population decline between 9500 and 8000 Cal yr BP, during the later PPNB and Pottery Neolithic A (PNA) periods (Fig. 2a). This coincided with, and was probably influenced by, an overall drying of the climate. While it is hard to detect palynological evidence of land cover changes during the Levantine Neolithic that could be unambiguously attributed to human activities, livestock grazing and biomass burning must have impacted on vegetation (Rollefson and Köhler-Rollefson, 1992; Turner et al., 2010) and may have contributed to the rather high early Holocene values for pollen of disturbed vegetation. 
After $7000 \mathrm{Cal}$ yr BP, there was an alternation over time between olive groves and evergreen oak shrub/woodland, notably in the Jordan River catchment, and these two pollen curves parallel archaeo-demographic trends closely. There were demographic peaks during the Chalcolithic-EBA-MBA (6500-3500 Cal yr BP) and again in Roman-Byzantine times (2100-1400 Cal yr BP; Fig. 2b). Both of these correspond to maxima in olive pollen, strongly suggesting that this represents cultivated rather than wild olive trees (Langgut et al. 2015 and 2016; Fig. 4b). The main exception to this linkage between rural population and olive cultivation occurred during early Iron Age times (3100-2700 Cal yr BP), when archaeological data appear to show a demographic peak while pollen evidence shows almost no olive cultivation and a dominance of evergreen oak woodland (Figs 2 and 4; see also Palmisano et al., 2019). This is the period of ancient Israel and Judea, which has been a major focus of field research over the past half-century, and it may have generated a biased archaeological ${ }^{14} \mathrm{C}$ and site survey record for this time period in parts of the southern Levant. According to archaeological site survey data, the pre-modern settlement maximum occurred around 2100-1400 Cal yr BP, and pollen and archaeological settlement both indicate a reduction in human impact on the landscape after this, when there was also a period of drier climate (Izdebski et al., 2016). Tree cover appears to have reached a pre-20th century maximum during Medieval times. Human transformation of land cover in this region is therefore clearly evident from $6500 \mathrm{Cal}$ yr BP, at least in the southern part of the Levant (Fig. 4a).

In southern Anatolia (Woodbridge et al., 2019), ${ }^{14} \mathrm{C}$ date SPD data show an initial Neolithic demographic rise after 10,300 Cal yr BP, with an inferred peak in population just before 8000 Cal yr BP (Fig. 2a; see also Roberts et al., 2018b). There is good archaeological evidence for the transition to village life and a farming economy in areas such as the Konya basin and Cappadocia at this time (Baird et al., 2018). The Neolithic demographic rise coincided with a period of wetter climate than today in the eastern Mediterranean (Finné et al., 2019). However, after 9500 Cal yr BP there was a climatic drying trend whose latter part coincided with a significant westward extension in Neolithic populations (Weninger et al., 2014) and which culminated in drought at the time of the 8.2 ka climate event (Dean et al. 2015; Roffet-Salque et al., 2018). After $~ 8000$ Cal yr BP there were important cultural changes at sites such as Çatalhöyük, alongside an apparent overall decline in population (Gülçur 2012). Southern Anatolian pollen sites are limited in number during the early Holocene, but show that South Central Anatolia was characterised by a grassland phase at this time (Turner et al., 2010), followed by the development of open oak parkland that may have been deliberately managed by early farming populations (Asouti and Kabukcu, 2014). Thus in this sub-region, there may never have been a pre-Neolithic base-line "natural 
vegetation". In contrast, Holocene forest cover was well developed in the uplands of southwest Anatolia by $\sim 8000 \mathrm{Cal}$ yr BP.

The central Anatolian oak parkland was maintained until about $4000 \mathrm{Cal}$ yr BP, after which it was replaced by pasture-land and by tree crops. Southern Anatolia experienced the wellknown Beyşehir Occupation Phase of agrarian land cover, including arboriculture (Bottema et al., 1986; Roberts 2018). A clear anthropogenic signal is consequently provided by the OJCV index, which increased after $\sim 5000$ Cal yr BP (EBA) before declining again at $\sim 1300$ Cal yr BP (mid-Byzantine; Fig. 4b). As in the Levant, there is a marked increase in AP\% pollen in the last 1300 years, mainly of pine, indicating re-forestation of previous anthropic land cover (Fig. 4a). The archaeological settlement record indicates several long-term demographic "cycles", in accord with Allcock's (2017) analysis from Cappadocia. They include settlement peaks during the Bronze Age (4700-3100 Cal yr BP) and again in the Hellenistic-Roman-early Byzantine period (2300-1300 Cal yr BP). Thus there is consequently evidence of possible human impact on land cover in South Central Anatolia back to Neolithic times, with clear human transformation of vegetation from the Bronze Age onwards. For the last 4700 years, there is a clear association between archaeologicallyinferred population and pollen-inferred land cover in this region.

For Greece as a whole, ${ }^{14} \mathrm{C}$ date data are available from our analyses as a population proxy, and Weiberg et al. (2019) have also included quantified settlement data for two smaller sub-regions, namely in the Peloponnese and Greek Macedonia. The latter are especially important in enabling comparison with pollen data for the last 2600 years when human impact reached a peak. Pollen data indicate a significant contrast between northern and southern Greece, with sclerophyllous parkland indicating anthropogenic landscape modification in southern Greece since the mid-Holocene. Grazing and disturbance indicators increase in the southern but not in the northern Greek pollen record after $~ 5000 \mathrm{Cal}$ yr BP, while in the first millennium $\mathrm{CE}$, there is evidence of agricultural decline and forest recovery (mainly pine) in the southern sub-region, but not in northern Greece (Fig. 4a). While both sub-regions show a relationship between the importance of tree crops (OJCV index; Fig. 4b) and reconstructed population levels, in southern Greece this is mainly via olive (Olea), whereas walnut (Juglans) provides a better indicator in northern Greece. Some of the olive pollen is likely to have been from wild rather than cultivated trees, particularly during the mid-Holocene, when there was a "mediterraneanization" of the climate, notably towards dry summers (Tzedakis 2007; Finné et al., 2019). The long-term trend was towards a decrease in forest cover, starting in the mid-Holocene and broadly coinciding with the demographic peak of Bronze Age times (4700-3100 Cal yr BP) as well as a drying of the climate after 4200 Cal yr BP (Figs. 2a and 4a). In contrast, there is no obvious change in anthropogenic 
land cover during the earlier, Neolithic population "bulge" (8300-6300 Cal yr BP). Two long demographic "cycles" are therefore evident from ${ }^{14} \mathrm{C}$ date SPDs, along with a third one in southern Greece starting in Archaic times (2700-2500 Cal yr BP) which reached a maximum in the late first millennium BCE (Classical Greek period).

The central Italy study region (Palmisano et al., 2017, 2018; Stoddart et al., 2019) possesses both archaeological ${ }^{14} \mathrm{C}$ SPDs and site survey data sets. These archaeodemographic data show two clear "boom and bust" cycles prior to Medieval times, followed by a third cycle in the last 1500 years, for which archaeo-demographic data are not available (Fig. 2). The first demographic cycle began with the Neolithic period and ended in the Bronze Age (7800 to $\sim 4000$ Cal yr BP), with the second commencing $\sim 3000$ BP, leading into the Etruscan period and ending with the fall of the western Roman Empire ( 1600 Cal yr BP). According to pollen-inferred land cover, the initial opening-up of deciduous oak forests occurred from $7500 \mathrm{Cal}$ yr BP, coinciding with demographic increase following the arrival of Neolithic farming (Robb 2007, p.26). Thus, it is possible that landscape management may have begun early here, leading to the development of parkland and shrub-land vegetation. The main increase in tree crops in this region occurred after $2800 \mathrm{Cal}$ yr BP (i.e. Etruscan and Latin periods) coincident with a further decline in woodland cover (Mercuri et al. 2002). Arboriculture is clearly attested through the period of Republican and Imperial Rome in the regional pollen record (Fig. 4b), after which there was an increase in non-cultivated tree pollen, associated with partial re-afforestation of the landscape. Notwithstanding the demographic evidence for dense rural settlement during the Roman period, the forest minimum and OJCV maximum did not occur at this time, but in Medieval and post-Medieval times.

The southern French case study region (Berger et al., 2019) has relatively good pollen coverage and both ${ }^{14} \mathrm{C}$ date and archaeological site data extending up to Medieval times, but few independent climate records. Comparison between the two archaeo-demographic proxies shows a good match between them until $2700 \mathrm{Cal}$ yr BP (Figure 3), but ${ }^{14} \mathrm{C} \mathrm{SPD}$ data unsurprisingly fail to capture the Roman settlement maximum (Figure 2). The archaeodemographic record suggests a series of long-term demographic "cycles", starting in the Neolithic-Chalcolithic (7500-3500 Cal yr BP), followed by Bronze Age population decline (4th mill BP), and renewed demographic increase during the first millennium BC leading into the Roman settlement peak (2100-1500 Cal yr BP). After post-Roman decline, there was renewed growth of population in early Medieval times (after $1100 \mathrm{Cal}$ yr BP).

Pollen-inferred land cover indicates that the main decline in forest cover has occurred in the last 2600 years (Fig. 4a), partly overlapping with the Roman-era peak in archaeological site 
numbers. This is most evident in upland Oro-Mediterranean sites (sub-region 2) and linked mainly to an increase in pasture-land. In Eu-Mediterranean lowland/coastal areas (subregion 1) there is evidence of an increase in parkland vegetation from Neolithic times that suggests landscape management at an earlier date, especially prior to $4000 \mathrm{Cal}$ yr BP (notably in late Neolithic times). The post-Roman decline in settlement is only weakly represented in the pollen record of land cover. A bigger change in land cover occurred in Medieval and post-Medieval times (including arboriculture), for which archaeo-demographic data are not available. Data have also been synthesised for the non-Mediterranean midRhône sub-region (see Berger et al., 2019).

Eastern Iberia (Fyfe et al., 2019) only has demographic data available from ${ }^{14} \mathrm{C}$ SPDs, which limits comparison with pollen data to the period before $2500 \mathrm{Cal}$ yr BP. Sub-regional analysis of land cover change is also hampered by low numbers of pollen sites in subregions 1 (northeast lberia) and 3 (Balearic Islands). The dominant trend in pollen-inferred land cover on mainland sites is a progressive decline in woodland since the mid-Holocene (Fig. 4a), with an increase in pastoral land (last 3000 years) and tree crops (last 2000 years). There is little sign in the pollen data of long-term cycles of land cover change. In terms of archaeo-demographics, there are some significant differences between different sub-regions, with a clear "boom and bust" cycle evident in southeast Spain (5000 to 3400 Cal yr BP). This is less evident in northeast lberia, where population appears to have grown steadily from the start of the Neolithic to 2500 Cal yr BP (Fig. 2a). There are some parallels between the pollen-inferred land cover and archaeo-demography in this sub-region, with the sharp rise in population at the Mesolithic/Neolithic transition (7400 Cal yr BP) coinciding with the start of decline in \%AP. However, late Holocene aridification of the climate probably contributed to vegetation change in eastern lberia, along with human land conversion. The socio-environmental history of the Balearics (Mallorca and Menorca) is distinct from the mainland, with late initial human settlement ( 5000 Cal yr BP), and population peaking early in the first millennium BCE before declining.

For Morocco too, archaeo-demographic data are only available from ${ }^{14} \mathrm{C}$ SPDs, limiting comparison with pollen evidence to the time period prior to $3000 \mathrm{Cal}$ yr BP. (Cheddadi et al., 2019). There is also a problem of spatial congruence in this region, in that most archaeological ${ }^{14} \mathrm{C}$ dates come from lowland sites, whereas a majority of pollen records come from the uplands of the Rif or the Atlas mountains. The clearest relationship between changes in archaeo-demography and pollen-inferred land cover comes from lowlands below 800 masl at the start of the Neolithic period, from around $7500 \mathrm{Cal}$ yr BP. This archaeological transition was marked by a clear rise in population to a peak at $\sim 7000 \mathrm{Cal}$ yr $\mathrm{BP}$, before declining to a demographic minimum at $\sim 5500 \mathrm{Cal}$ yr BP - a sequence of "boom 
and bust" seen in several regions of the Mediterranean during the early Neolithic (Shennan, 2018; ch. 5). At the same time (i.e. $7500 \mathrm{Cal}$ yr BP), there was a sharp fall in tree pollen in lowland sites followed by an increase in the pollen of ruderals and other disturbance indicators. While this would be consistent with deforestation by the first farming communities in North Africa, it should be borne in mind that only two lowland pollen records are available for this time interval, both of them archaeological cave sites, where human impact is likely to have been most easily detected. In upland regions of Morocco, human activities are not detectable palynologically until much later in the Holocene, and the clearest anthropogenic evidence dates to the last two millennia, for which archaeo-demographic data are not available. In Morocco's uplands, forests of cedar and oak appear to have persisted with relatively modest human disturbance until recent times.

\section{Analysis and discussion}

As set out at the start of this paper, three potential causal relationships can be hypothesised from the data sets described above, namely 1) impact of climate change on vegetation and land cover, 2) impact of climate change on human populations, 3) impact of human populations on land cover. We can examine these possible causal linkages via statistical correlations between relevant proxy indicators, when and where they overlap in space and time. However, statistical correlation assumes that chronologies are perfectly aligned and that there are no lag effects (although the latter can be accounted for by using t-1, t-2, etc). There is also the possibility that relationships operated only for limited periods of time, which requires the use of moving-window correlations (see Palmisano et al., 2019 and Stoddart et al., 2019, for examples). Alternatively society-environment relationships may have been spatially and temporally diverse as a consequence of technological innovation and contrasting approaches to resource appropriation and management (e.g. conservationist groups which are highly resilient vs exploitative strategies with destructive lock-ins; see Rosen 2007, for examples).

For these reasons, there is merit in comparing proxies graphically as well as statistically. Where possible, we have analysed data at a sub-regional as well as at a regional level; e.g. southern and northern Greece analysed separately.

For statistical correlations we have used the following representative proxy indicators

- Population: SPDs of ${ }^{14} \mathrm{C}$ dates and aoristic sum of archaeological site numbers

- Land cover: \%NAP, \%OJCV, API, grazing indicators 
- Hydro-climate z-scores

Population vs land cover: it is often stated (e.g. Hughes, 2014) that Mediterranean environmental history is largely one of human-induced deforestation. It is true that there has been an overall decline in Mediterranean tree cover during the Holocene (as indicated by $\% \mathrm{AP})$ at the same time that human population sizes have risen. This is, of course, also true in many other regions, such as temperate Europe (Roberts et al., 2018a), including the midRhône valley (southern France sub-region 3). The Spearman's Rank ( $\rho$ ) correlations shown in table 3 indicate statistically-significant negative relationships, with high $R^{2}$ values between tree cover (\%AP) and human population in 6 out of 11 Mediterranean sub-regions for SPDs of ${ }^{14} \mathrm{C}$ dates, and in 6 out of 8 sub-regions for aoristic sum of settlement numbers. The stronger relationship with the aoristic sum data partly reflects the fact that these data extend into historic times, whereas the SPDs of ${ }^{14} \mathrm{C}$ dates apply only to the pre- and proto-historic time period (prior to 2500 Cal. yr BP); clearly, much deforestation took place in Classical times. None the less, the relationship "more people = fewer trees" has not been the case everywhere in the Mediterranean, and in the Levant, the reverse has been true. Here there has been a statistically significant increase in tree cover as human populations have grown during the Holocene, whether using SPD of ${ }^{14} \mathrm{C}$ dates or aoristic sum of settlement data as a proxy. Some of this can be explained by the large-scale cultivation of tree crops during the later Holocene, but even if these are excluded from the AP sum the correlation remains positive and significant.

In fact, there is a clear geographical pattern in the relationship between changes in tree cover and in human populations, one that is based on the initial (i.e. early-mid Holocene) forest extent (table 2). In the wetter and better-wooded regions of the Mediterranean (e.g. northern Italy, northeast Iberia and Oro-Mediterranean France) human population growth shows a clear relationship with declining tree cover (see Fig. 4a). In drier regions, where tree cover was never so well developed, this relationship breaks down. This can be seen by performing a linear regression to model the relationship between the mean AP\% for each region/sub-region during the period 10,000 and 4000 Cal yr BP and the Spearman's correlation between AP\% and population during the Holocene (Figure $5 \mathrm{a}$ ). In areas where mean $\mathrm{AP} \%$ was $>65 \%$ during the early-mid Holocene, then increases in human population represent a strong predictor of forest decline. In contrast, in the Levant, where initial mean AP\% was only $\sim 30 \%$, the historic increase in human population appears to have had a positive overall impact on woodland cover, although altering its structure and species composition. In semi-arid regions such as southern Greece and southeast Iberia, where mean AP\% prior to $4000 \mathrm{Cal}$ yr BP was in the range $30-60 \%$, there has been no clear 
relationship between the number of people and the number of trees over time. Further regional analyses would be needed to confirm this apparent trend.

The strongest relationship between human population and pollen-inferred land cover in the Mediterranean is not with overall tree cover, but with tree crops, as indicated by the OJCV index (table 3). There are positive and statistically significant relationships between both archaeo-demographic indicators and the OJCV index in almost all study regions, including the Levant. The main exception to this is southeast Spain, where only ${ }^{14} \mathrm{C}$ SPD data are available and where population reconstruction therefore ends prior to the main expansion of tree crop cultivation during the last two and a half millennia. As noted above, OJCV includes pollen of wild as well as domestic olive and chestnut trees, and hence does not always represent a clear index of human land use in regions where these species are common naturally (c.f. Conedera et al 2004). Even so, our results suggest that OJCV provides the best palynological indicator of anthropogenic activity in the Mediterranean. This pollen index shows a much stronger statistical relationship to past human population than either the API or grazing indicators (table 3). Both of these show a positive relationship with the aoristic sum (site numbers) in most regions, but not with ${ }^{14} \mathrm{C}$ SPD data (i.e. during prehistory) except in north central Italy. As with overall tree cover, there is an inverse relationship between these pollen indices and inferred population in the Levant. It seems that the pollen taxa used in the API and grazing indices can provide useful measures of anthropogenic activity in climatically humid, well-wooded regions, but not in drier regions of the Mediterranean, where vegetation disturbance through summer drought, wildfire and grazing have been long-standing.

Climate vs human population. There has obviously been a huge increase in human population during the course of the Holocene. At the same time there has been an overall trend towards climatic desiccation in southern and eastern parts of the Mediterranean. Consequently in regions such as the Levant and Anatolia, there is an overall negative correlation between climatic moisture availability and demographic trajectories (see also Jones et al., 2019). In other words, human populations have grown in these areas despite, not because of, the long-term climate trajectory; for example, by the use of new technologies, such as irrigation, and crop and livestock breeding (Rosen, 1987; Langgut et al., 2016). This is not to say that periods of adverse climatic conditions (e.g. extended drought) did not have negative societal consequences over decadal to centennial timescales. Over multi-millennial timescales, on the other hand, climatic adversity appears to have acted as a prompt and stimulus to innovation rather than retarding societal development in these regions (c.f. Rosen, 2007). 
Climatic changes during the Holocene could also have influenced human developments in other ways. For example, the overall pattern of climate change in the Mediterranean over the last eight millennia has involved a regional see-saw in which southern and eastern regions have overall become drier relative to areas to the north and west (Finné et al., 2019). It might be argued that this gave a climatic advantage to populations in regions such as northern Italy, northeast Iberia and southern France relative to North Africa and Southwest Asia during the last two millennia. However, any such effects would have operated slowly and indirectly, and some major imperial powers, such as Egypt, functioned largely independently of climatic conditions prevailing in the Mediterranean. There were no simple cause and effect mechanisms at work here, and no statistically significant relationships are evident between Holocene trends in climatic moisture availability and human population in regions such as central Italy (table 3 ).

There is evidence, however, for a positive correlation between hydro-climate and population in some regions for specific time intervals, with the clearest example of this being northern Greece between 9700 and $4300 \mathrm{Cal}$ yr BP (Fig. 6b). ${ }^{14} \mathrm{C}$ SPD data from this sub-region record a major demographic increase associated with the initial spread of Neolithic farming at the same time as proxy records show an increase in climatic moisture (8900-8300 Cal yr BP). An equivalent relationship applies to the Final Neolithic population minimum (5900$4900 \mathrm{Cal}$ yr BP) that coincided with a period of climatic desiccation, before population recovered during the Early Bronze Age. The positive correlation between climate and demography in this sub-region only breaks down with the development of complex societies in the Middle and Late Bronze Age of the 2nd millennium BC. There were similar positive climate-demography relationships in southern Greece from 7000 to $4000 \mathrm{Cal} y \mathrm{BP}$, and in north central Italy from 6000 to $3000 \mathrm{Cal}$ yr BP, in both cases based on SPD data (Figures $5 \mathrm{~b}$ and $5 \mathrm{c}$ ). These relationships suggest that the connection between climate and demography was closest in early farming communities (i.e. Neolithic-Chalcolithic), prior to the emergence of complex stratified societies and trading networks in the later Bronze and Iron Ages (Rosen 2007, p.101). There may have been a hinge point some time between 6000 and 3000 Cal yr BP when recurring climatic "crises" helped prompt new societal developments that helped to free people and food production from direct dependence on weather conditions.

Climate vs land cover. There is a well-founded and substantial body of literature exploring the relationship between Holocene climate and pollen-inferred vegetation and land cover in the Mediterranean (e.g. Tzedakis, 2007; Jalut et al., 2009; Fletcher et al., 2013; Guiot and Kaniewski, 2015), which we do not seek to repeat here. Instead we focus on the relationship between pollen indices potentially linked to past human activities (e.g. OJCV) and non- 
palynological records of Mediterranean hydro-climate, to establish how far the latter could provide an alternative explanation for observed land cover changes. Based on regional zscores, table 3 shows no statistical relationship between climate changes and overall tree cover in north central Italy, northern or southern Greece. In the Levant, as noted above, there is a statistically significant inverse relationship between \%AP and climatic aridity during the Holocene; i.e. tree cover increased as the climate became drier. Only in southern Anatolia was there a positive and statistically significant relationship between tree cover and climatic humidity during the last ten millennia. The woodland maximum here occurred between $\sim 8000$ and $\sim 6000$ cal yr BP at a time when climate was overall wetter, while the forest minimum ( 5000 to $1300 \mathrm{Cal}$ yr BP) overlapped in time with the period of driest climate (Woodbridge et al., 2019). Even so, there are anomalies to this relationship, including the fact that \%AP declined before the biggest shift in climate at $\sim 5300 \mathrm{Cal} \mathrm{yr} \mathrm{BP}$, suggesting that climatic desiccation on its own cannot explain the reduction in tree cover.

Table 3 indicates that changes in Holocene tree cover in Greece and north central Italy since $10,000 \mathrm{Cal}$ yr BP are explained better by rises and falls in human population than by shifts in climate. In northeast Iberia and France's Oro-Mediterranean region too, there has been a statistically significant relationship between population density and tree cover. In aggregate these results cast doubt on the assertion that climate was the "main factor pacing the centennial- to millennial-scale phases of forest development and decline" in the western and central Mediterranean during the Holocene (De Rita et al., 2018). This is not to say that changes in climate have not exerted a major influence on forest composition or contributed to woodland decline since mid-Holocene times (Woodbridge et al., 2018; Fyfe et al., 2018). However, it does imply that \%AP is unlikely to provide a "clean" signal of Holocene climatic variations in the Mediterranean.

Equally interesting is the relationship between the OJCV index and Holocene climate. As discussed above, OJCV has the strongest positive correlation of all pollen indices with archaeologically-inferred past population, linked to the long-standing role played by tree crops in Mediterranean agriculture. In several regions, the rise in OJCV pollen coincides with a mid-Holocene shift to drier climatic conditions, as registered by hydro-climate zscores. In southern Greece and the Levant this occurred around $7000 \mathrm{Cal}$ yr BP, while in southern Anatolia it took place later, around $5500 \mathrm{Cal}$ yr BP (figure 6). Mid-Holocene climatic desiccation led to a "mediterraneanization" of vegetation cover, with droughtadapted, sclerophyllous taxa, such as olive, becoming more common. The increase of olive on the Balearic islands at this time has been interpreted as the result of such a shift to a summer-dry climate (Burjachs et al., 2015). On the other hand, it is clear that by $6500 \mathrm{Cal}$ yr BP there was large-scale cultivation of olive trees in the Levant (Langgut et al. 2019), and 
this was also true of southern Greece and parts of Anatolia by $4000 \mathrm{Cal}$ yr BP. The midHolocene rise in the OJCV index in the eastern Mediterranean may therefore represent an example of a growing prevalence of both wild and domestic olive trees under the combined influence of climatic desiccation and human modification. As a perennial crop, olive and other cultivated trees offered a buffer against year-to-year fluctuations in rainfall and hence some freedom from the direct dependence of cereal-based agriculture on climate. The Neolithic economy would have become increasingly precarious under the drier, and probably less reliable, climate after $\sim 6000 \mathrm{Cal}$ yr BP, and drought-adapted olive trees represented a viable and ultimately highly successful alternative strategy, both agrarian and ecological.

The status of tree crops such as olive as early 'domesticates' is obviously contested (Langgut et al., 2019), but it must have related to the management of wild plant resources by small-scale agrarian societies at the start of the Chalcolithic period in regions such as the Levant. Initially this would have involved the construction of niches to maintain and enhance cropping of 'wild' woodland resources (Smith 2011a, 2011b). Over time, and with increasing yields, this became formalised as true silviculture from $\sim 6500 \mathrm{Cal}$ yr BP onwards, as seen in the OJVC pollen index for this region.

\section{Conclusion}

The data sets discussed in this synthetic paper represent records of long-term changes in demography, land cover and climate. Because these sources of data are independent of each other, and if they derive from the same geographical region and are put onto a common timescale, then it is possible to test causal relationships between them. As proxies for past population, SPDs of ${ }^{14} \mathrm{C}$ dates can be used up until $\sim 2500 \mathrm{Cal}$ yr BP, while regional site survey data extend until $\sim 1000$ Cal yr BP. Comparison between these two archaeological data sources indicates good overall correspondence where they overlap in time. Results show that most Mediterranean regions experienced a series of population "cycles" starting with the first appearance of Neolithic farming societies, but that demographic trends were region-specific rather than pan-Mediterranean. The one exception to this occurred between 2200 and 1400 Cal yr BP during Roman Imperial rule, when there was a synchronous population maximum across all regions. This coincided with the peak in Mediterranean-wide production and exchange systems for grain, wine and olive oil. While unsurprising, this highlights how far the Roman period of Mediterranean-wide hegemony was exceptional when viewed on a Holocene timescale. 
The quasi-cyclical pattern evident in archaeo-demographic data sets is less obvious in pollen data. Palaeo-environmental evidence supports the idea that periods of land-use intensification in the Mediterranean alternated with periods of de-intensification (Butzer 2005). However, landscape impacts were cumulative over time, so that vegetation did not return to its previous condition at the end of each demographic cycle, even if there was partial recovery. As a proxy for deforestation, \%AP shows a clear correlation with human population trends in those parts of the Mediterranean that were initially well wooded, such as northern Italy. In these regions, pollen-inferred overall forest cover correlates more closely with archaeologically-inferred human activity than with proxies of regional climate change. Here and also in drier, less well-wooded Mediterranean regions, the best pollenbased measure for human-induced land cover change comes not from negative correlations with \%AP but from positive correlations with the OJCV tree crop index. The rise in cultivation of tree crops in the eastern Mediterranean could be seen as an adaptive response to mid-Holocene climatic desiccation, as the previously reliable cereal-based Neolithic agrarian system became vulnerable to weather-related crop failure. In regions such as the Levant and southern Anatolia, the pre-20th century forest minimum and demographic maximum occurred in Classical times, after which there was re-afforestation and partial landscape recovery. The dominant landscape trajectory in the eastern Mediterranean during the last 1500 years thus therefore stands in contrast to that in the central and western Mediterranean.

Synthesised pollen data for the Mediterranean as a whole show multi-centennial variability in land cover that was superimposed on longer-term multi-millennial trends, firstly towards a more stable landscape ecology during the early Holocene (prior to $~ 8600 \mathrm{Cal}$ yr BP), and then in the later Holocene towards greater landscape disturbance and faster vegetation turnover, notably after $\sim 3500 \mathrm{Cal}$ yr BP (Figure 7). Hydro-climatic z-score records highlight a wetter early Holocene climate in most of the Mediterranean except the northwest, followed by a transition to drier climatic conditions during mid-Holocene times. This trend in moisture availability is in good accord with the long-term pattern of vegetation change up to $3500 \mathrm{Cal}$ yr BP, with forest extent reaching a maximum during the early Holocene (9500-8500 Cal yr $\mathrm{BP})$ and then progressively diminishing during the mid-Holocene climatic transition. However, the trend towards climatic desiccation ended by $3000 \mathrm{Cal}$ yr BP, and in several Mediterranean regions hydro-climate became slightly wetter during the last three millennia. Despite this, pollen evidence indicates that Mediterranean landscapes became increasingly open after this time, implying a progressive de-coupling of climate and vegetation, even if climate would have continued to have exerted an influence, for example, on forest composition. 
The initial decline in forest cover overlapped in time with the adoption of Neolithic farming, which spread from southwest Asia across most parts of the Mediterranean between $~ 9000$ and 7500 BP (Broodbank, 2013, p. 185). Similarly, the gradual opening of Mediterranean landscapes between 7500 and $3000 \mathrm{Cal}$ yr BP coincided with demographic rise and the emergence of complex, socially-stratified societies between the late Neolithic and the Iron Age (Fig. 7). Thus, both human impact and climate change seem likely to have been responsible for land-cover changes during the mid-Holocene. However, the increase in open landscapes after 3000 Cal yr BP (i.e. in Classical-Medieval-Modern times) is consistent with anthropogenic but not with climatic causation. Thus Mediterranean landscapes represent a mosaic, reflecting the distinctive historical trajectories of different regions. This highlights the importance of undertaking analysis at regional, sub-regional and, where possible, microregional scales, to avoid assuming simplistic causal relationships.

In summary, we have shown (a) that the relationship between human demographics and tree cover has been neither unilinear nor direct, (b) that the clearest manifestation of human action for Mediterranean land cover during the Holocene has been the creation of cultural landscapes based around olive groves, vineyards and other tree crops, a process that was constructive (i.e. planting, tending....) as much as destructive (i.e. tree cutting, burning...), (c) that human populations can expand in spite, as well as because, of longer-term changes in climate, due to both technical and societal/organisational adaptive strategies, (d) that climatic adversity can therefore act as a stimulus as much as a hindrance to social evolution.

\section{Acknowledgements}

This research has been funded by Leverhulme Trust grant RPG-2015-031. Pollen data were extracted from the European Pollen Database and the work of the data contributors and the EPD community is gratefully acknowledged. This research is a contribution to the Past Global Changes (PAGES) project and its working group LandCover6k. We especially thank Martin Finné, Inga Labuhn, Erika Weiberg, Markos Katsianis, Joan Estrany, Graeme Barker and two anonymous reviewers for their help. Tim Absalom of the University of Plymouth Geomapping unit assisted with graphics. 


\section{References}

Abulafia, D. 2011 The Great Sea: A Human History of the Mediterranean. Oxford University Press.

Allcock, S.L. (2017) Long-term socio-environmental dynamics and adaptive cycles in Cappadocia, Turkey during the Holocene. Quaternary International 446: 66-82.

Asouti, E. and Fuller, D.Q. (2012) From foraging to farming in the Southern Levant: The development of Epipalaeolithic and Pre-Pottery Neolithic plant management strategies. Vegetation history and archaeobotany 21(2), 149-162.

Asouti, E. and Kabukcu, C. (2014) Holocene semi-arid oak woodlands in the Irano-Anatolian region of Southwest Asia: natural or anthropogenic? Quaternary Science Reviews 90: 158-182.

Baird, D., Fairbairn, A., Jenkins, E., et al. (2018) Agricultural origins on the Anatolian plateau. Proceedings of the National Academy of Sciences of the United States of America.

Barker, G. (2005) Agriculture, Pastoralism, and Mediterranean Landscapes in Prehistory: in The Archaeology of Mediterranean Prehistory, Blake, E. and Knapp, A.B. (Eds) WileyBlackwell, pp.46-76..

Berger, J.-F., Shennan, S., Woodbridge, J. et al. (2019, this volume) Holocene Land Cover and Population Dynamics in Southern France. The Holocene

Bevan, A., Greenberg, R., Knappett, C., Lawall, M., Meneley, A., Purcell, N., Sherratt, E.S., Smail, D.L. and Bevan, A. (2014) Mediterranean containerization. Current Anthropology 55(4), 387-418.

Bevan, A. Palmisano, A., Woodbridge, J., Fyfe, R., Roberts, N. and Shennan, S. (2019, this volume) The changing face of the Mediterranean: introduction and overview. The Holocene

Bintliff, J. and Sbonias, K. (eds) (1999) Reconstructing past population trends in Mediterranean Europe. Oxford. 
Bottema, S., Woldring, H. and Aytuğ, B. 1986: Palynological investigations on the relation between prehistoric man and vegetation in Turkey: the Beyşehir Occupation Phase. In Demiriz, H. and Özhatay, N., editors, Proceedings of the 5th OPTIMA Meeting, Istanbul, pp. 315-28.

Broodbank, C. (2009) The Mediterranean and its hinterland. In: B. Cunliffe, C. Gosden, and R. A. Joyce (Eds), The Oxford Handbook of Archaeology. Oxford: Oxford University Press, pp. $678-714$.

Broodbank, C. (2013) The Making of the Middle Sea: A History of the Mediterranean from the Beginning to the Emergence of the Classical World. Thames \& Hudson.

Burjachs, F., Pérez-Obiol, R., Picornell-Gelabert, L., Revelles, J., Servera-Vives, G., Expósito, I. and YII, E.-I. (2017) Overview of environmental changes and human colonisation in the Balearic Islands (Western Mediterranean) and their impacts on vegetation composition during the Holocene. Journal of Archaeological Science: Reports 12: 845-859.

Butzer, K.W. (2005) Environmental history in the Mediterranean world: cross-disciplinary investigation of cause-and-effect for degradation and soil erosion. Journal of Archaeological Science, 32(12), 1773-1800.

Cheddadi, R., Palmisano, A., Woodbridge, J. et al. (2019, this volume) Human demography changes in Morocco and environmental imprint during the Holocene. The Holocene

Collins, P.M, Davis, B.A.S. \& Kaplan, J.O. (2012) The mid-Holocene vegetation of the Mediterranean region and southern Europe, and comparison with the present day. $J$. Biogeogr. 39, 1848-1861.

Conedera, M., Krebs, P., Tinner, W., Pradella, M. and Torriani, D. (2004) The cultivation of Castanea sativa (Mill.) in Europe, from its origin to its diffusion on a continental scale. Vegetation History and Archaeobotany, 13(3), 161-179.

Crema, E.R. (2012) Modelling temporal uncertainty in archaeological analysis. Journal of Archaeological Method and Theory 19(3), 440-461. 
Dean, J.R., Jones, M.D., Leng, M.J., et al. (2015) Eastern Mediterranean hydroclimate over the late glacial and Holocene, reconstructed from the sediments of Nar lake, central Turkey, using stable isotopes and carbonate mineralogy. Quaternary Science Reviews 124: $162-174$.

Di Rita, F., Fletcher, W.J., Aranbarri, J., Margaritelli, G., Lirer, F., Magri, D. (2018) Holocene forest dynamics in central and western Mediterranean: periodicity, spatio-temporal patterns and climate influence. Scientific Reports 8, 8929.

Drake, B.L., Blanco-González, A. and Lillios, K.T. (2017) Regional demographic dynamics in the Neolithic transition in Iberia: results from summed calibrated data analysis. Journal of Archaeological Method and Theory 24: 796-812.

Finné, M., et al (2011) Climate in the eastern Mediterranean, and adjacent regions, during the past 6000 years - a review. J. Arch. Sci. 38: 3153-3173.

Finné, M., Woodbridge, J., Labuhn, I. and Roberts, N. (2019, this volume) Holocene hydroclimatic variability in the Mediterranean: a synthetic multi-proxy reconstruction. The Holocene

Fletcher, W.J., Debret, M. and Sanchez Goñi, M. F. (2013) Mid-Holocene emergence of a low-frequency millennial oscillation in western Mediterranean climate: Implications for past dynamics of the North Atlantic atmospheric westerlies. The Holocene 23, 153-166

Flohr, P., Fleitmann, D., Matthews, R., et al. (2016) Evidence of resilience to past climate change in Southwest Asia: Early farming communities and the 9.2 and 8.2 ka events. Quaternary Science Reviews 136: 23-39.

Fyfe, R.M., Woodbridge, J., Palmisano, A. et al. (2019, this volume) Prehistoric palaeodemographics and regional land cover change in eastern lberia. The Holocene

Fyfe, R., Woodbridge, J. and Roberts, C.N. (2018) Trajectories of change in Mediterranean Holocene vegetation through classification of pollen data. Vegetation History and Archaeobotany 27: 351-364

Giesecke T., Davis, B., Brewer, S. et al. (2014) Towards mapping the late Quaternary vegetation change of Europe. Vegetation History and Archaeobotany 23: 75-86. 
Guiot, J. and Kaniewski, D. (2015) The Mediterranean Basin and Southern Europe in a warmer world: what can we learn from the past? Frontiers in Earth Science, 3, p.28.

Gülçur, S. (2012) The Chalcolithic Period in Central Anatolia Aksaray-Niğde Region. OriginiXXXIV, Nuova Serie V, 213-227.

Hofmanová, Z., Kreutzer, S., Hellenthal, G., Sell, C., Diekmann, Y., Díez-del-Molino, D., van Dorp, L., López, S., Kousathanas, A., Link, V. and Kirsanow, K. (2016) Early farmers from across Europe directly descended from Neolithic Aegeans. Proceedings of the National Academy of Sciences 113(25), 6886-6891.

Horden, P. and Purcell, N. (2000) The Corrupting Sea: a Study of Mediterranean History. Blackwell.

Hughes, J.D. (2014) Environmental problems of the Greeks and Romans. 2nd ed. John Hopkins University Press.

Izdebski, A., Pickett, J., Roberts, N. and Waliszewski, T. (2016) The environmental, archaeological and historical evidence for regional climatic changes and their societal impacts in the Eastern Mediterranean in Late Antiquity. Quaternary Science Reviews 136: 189-208.

Jalut, G et al. (2009) Holocene circum-Mediterranean vegetation changes: Climate forcing and human impact. Quaternary International 200. 4-18.

Jones, M.D. et al., (2019, in press) 20,000 years of societal vulnerability and adaptation to climate change in southwest Asia. WiRES Climate Change

Kaniewski, D. and Van Campo, E. (2017) The 3.2 kyr BP event and the Late Bronze Age crisis, a climate-induced spiral of decline. In: Weiss $\mathrm{H}$ (ed.) Megadrought and collapse. Oxford University Press, Oxford, pp 161-182.

Kaniewski, D., Paulissen, E., Van Campo, E., Al-Maqdissi, M., Bretschneider, J. and Van Lerberghe, K., 2008. Middle East coastal ecosystem response to middle-to-late Holocene abrupt climate changes. Proceedings of the National Academy of Sciences 105(37), 13941-13946.

Langgut, D., Finkelstein, I., Litt, T., Neumann, H. F. and Stein, M. (2015) Vegetation and climate changes during the Bronze and Iron Ages ( 3600-600 BCE) in the Southern Levant based on palynological records. Radiocarbon 57, 217-35. 
Langgut, D., Adams, M.J. and Finkelstein, I. (2016) Climate, settlement patterns and olive horticulture in the Southern Levant during the Early Bronze and Intermediate Bronze Ages (c. 3600-1950 BC). Levant 48(2), 117-134.

Langgut, D., Roberts, N., Woodbridge, J. et al. (2019, this volume) The origin and spread of olive cultivation in the Mediterranean Basin: the fossil pollen evidence. The Holocene

Leydet, M. (2007-2018) The European Pollen Database. (Online: http://www.europeanpollendatabase.net/).

Magny, M., Combourieu-Nebout, N., de Beaulieu, J. L. et al (2013) North-south palaeohydrological contrasts in the central Mediterranean during the Holocene: tentative synthesis and working hypotheses. Climate of the Past 9 (5): 2043-71.

Mather, A.S. and Needle, C.L. (1998) The forest transition: a theoretical basis. Area, 30(2), 117-124.

Mazier, F., Galop, D., Brun, C., et al. (2006) Modern pollen assemblages from grazed vegetation in the western Pyrenees, France: a numerical tool for more precise reconstruction of past cultural landscapes. The Holocene 16(1): 91-103

Meller, H., Arz, H.W, Jung, R \& Risch, R. (eds) (2015) 2200 BC_A climatic breakdown as a cause for the collapse of the old world? 7th Archaeological Conference of Central Germany, Landesmuseum für Vorgeschichte: Halle (Saale).

Mercuri, A.M., Accorsi, C.A. and Mazzanti, M.B. (2002) The long history of Cannabis and its cultivation by the Romans in central Italy, shown by pollen records from Lago Albano and Lago di Nemi. Vegetation History and Archaeobotany 11(4), 263-276.

Mercuri, A.M., Mazzanti, M.B., Florenzano, A., Montecchi, M.C. and Rattighieri, E. (2013) Olea, Juglans and Castanea: the OJC group as pollen evidence of the development of human-induced environments in the Italian peninsula. Quaternary International, 303, 2442.

Palmisano, A., Bevan, A. and Shennan, S. (2017) Comparing archaeological proxies for long-term population patterns: An example from central Italy. Journal of Archaeological Science 87, 59-72.

Palmisano, A., Bevan, A. and Shennan, S. (2018) Regional Demographic Trends and Settlement Patterns in Central Italy: Archaeological Sites and Radiocarbon Dates. Journal of Open Archaeology Data, 6(1), p.2. DOI: http://doi.org/10.5334/joad.43 
Palmisano, A. Woodbridge, J., Roberts, C.N. et al (2019, this volume) Holocene landscape dynamics and long-term populations trends in the Levant. The Holocene

Pons, A. and Quézel, P. (1998) A propos de la mise en place du climat méditerranéen. Comptes Rendus de I'Académie des Sciences-Series IIA-Earth and Planetary Science. 327(11), 755-760.

Robb, J. (2007) The early Mediterranean village: agency, material culture, and social change in Neolithic Italy. Cambridge: Cambridge University Press.

Roberts, N. (2018) Re-visiting the Beyşehir Occupation phase: land-cover change and the rural economy in the eastern Mediterranean during the first millennium CE. Eds: Mulryan M. and Izdebski A. Late Antique Archaeology.

Roberts, N., Eastwood, W.J., Kuzucuoğlu, C., Fiorentino, G. and Caracuta, V. (2011) Climatic, vegetation and cultural change in the eastern Mediterranean during the midHolocene environmental transition. The Holocene 21, 147-162.

Roberts, N., Fyfe, R.M., Woodbridge, J., Gaillard, M-J., Davis, B.A.S., Kaplan, J.O., Marquer, L., Mazier, F., Nielsen, A.B., Sugita, S., Trondman, A.-K. and Leydet, M. (2018a) Europe's lost forests: a pollen-based synthesis for the last 11,000 years. Scientific Reports 8: 716

Roberts, N., Woodbridge, J., Bevan, A., et al. (2018b) Human responses and nonresponses to climatic variations during the last Glacial-Interglacial transition in the eastern Mediterranean. Quaternary Science Reviews 184: 47-67.

Rollefson, G.O. and Köhler-Rollefson, I. (1992) Early Neolithic exploitation patterns in the Levant: cultural impact on the environment. Population and Environment, 13(4) 243-254.

Roffet-Salque, M., Marciniak, A., Valdes, P.J. Pawłowska, K. Pyzel, J. Czerniak, L., Krüger, M., Roberts, N., Pitter, S. and Evershed, R.P. (2018 in press) Evidence for impact of the 8.2 kyr BP event on Near Eastern Neolithic farmers from multi-proxy records and climate modelling. Proceedings of the National Academy of Sciences

Rosen, A.M. (1987) Phytolith studies at Shiqmim. In: Shiqmim, I., Levy, T.E. (Eds.), Shiqmim I: Studies Concerning Chalcolithic Societies in the Northern Negev Desert, Israel (1982-1984). British Archaeological Reports International Series 356. Oxford: Archeopress, pp. 243-250. 
Rosen, A.M. (2007) Civilizing climate: social responses to climate change in the ancient Near East. Lanham, MD: Altamira Press.

Shennan, S. (2018) The First Farmers of Europe: An Evolutionary Perspective. Cambridge University Press.

Smith, B.D. (2011a) A cultural niche construction theory of initial domestication. Biological Theory 6, 260-271.

Smith, B.D. (2011b) General patterns of niche construction and the management of 'wild' plant and animal resources by small-scale pre-industrial societies. Philosophical Transactions of the Royal Society of London B: Biological Sciences, 366, 836-848.

Stoddart, S., Woodbridge, J., Palmisano, A., et al. (2019, this volume) Tyrrhenian central Italy: Holocene population and landscape ecology. The Holocene

Turner, R., Roberts, N., Eastwood, W.J., et al. (2010) Fire, climate and the origins of agriculture: micro-charcoal records of biomass burning during the last glacial-interglacial transition in Southwest Asia. Journal of Quaternary Science 25: 371-386.

Tzedakis, P.C. (2007) Seven ambiguities in the Mediterranean palaeoenvironmental narrative. Quaternary Science Reviews, 26, 2042-2066.

Walker, M.J., Berkelhammer, M., Björck, S., Cwynar, L.C., Fisher, D.A., Long, A.J., Lowe, J.J., Newnham, R.M., Rasmussen, S.O. and Weiss, H. (2012) Formal subdivision of the Holocene Series/Epoch. Journal of Quaternary Science, 27, 649-659.

Walsh, K. (2014) Mediterranean Landscape Archaeology: An environmental perspective, Cambridge: Cambridge University Press.

Weiberg, E., Bevan, A., Woodbridge, J. et al. (2019, this volume) Long-term trends of land use and demography in Greece: a comparative study. The Holocene

Weninger, B., Clare, L., Gerritsen, F., Horejs, B., Krauß, R., Linstädter, J., Özbal, R. and Rohling, E.J. (2014) Neolithisation of the Aegean and Southeast Europe during the 6600-6000 cal BC period of Rapid Climate Change"? Documenta Praehistorica XLI, 131. DOl>10.4312ldp.41.1

Woodbridge, J., Roberts, N. and Fyfe, J. (2018) Pan-Mediterranean Holocene vegetation and land-cover dynamics from synthesised pollen data. J. Biogeography 45, 2159-2174. DOI: $10.1111 /$ jbi.13379 
Figure 1: Map of the Mediterranean with regional case study areas, showing site locations of pollen, climate and archaeological datasets

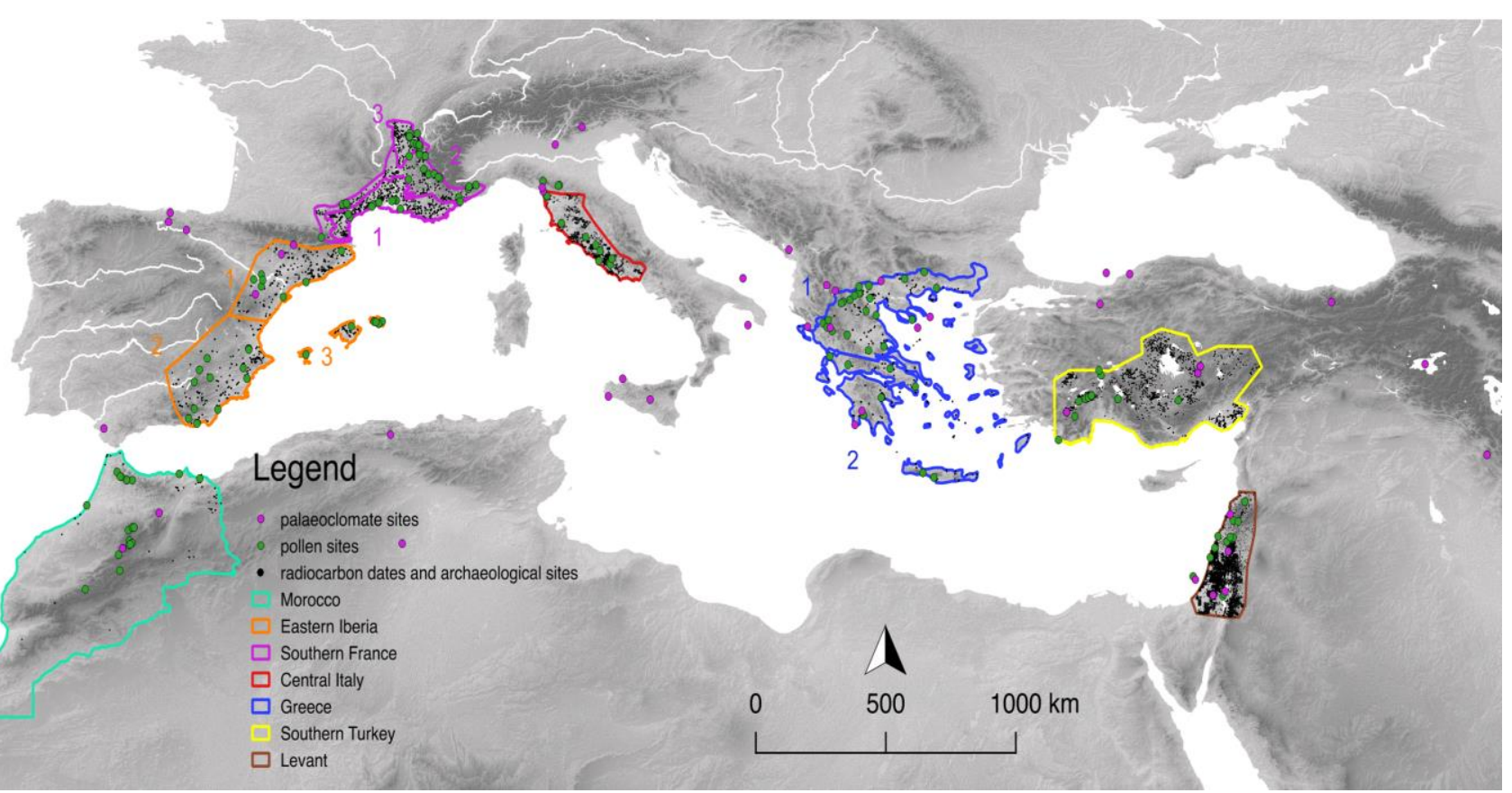


Figure 2: Archaeo-demographic trends for all regions and time periods, a) based on Summed Probability Density (SPDs) of ${ }^{14} \mathrm{C}$ dates, b) archaeological site surveys. Grey shading indicates the time periods for which ${ }^{14} \mathrm{C}$ SPDs are not considered to be a reliable demographic proxy. The black line indicates the date of the start of the Neolithic period in different regions. For France, sub-region 1=Eu-Mediterranean, sub-region 2=OroMediterranean, sub-region 3=mid-Rhône; for lberia, sub-region 1=northeast lberia, subregion 2=southeast Iberia, sub-region 3=Balearic Islands; for Greece, sub-region 1=northern Greece, sub-region 2=southern Greece.

Figure 3: Archaeo-demographic trends for southern France, Levant and central Italy prior to 2700 Cal yr BP, using different methodologies

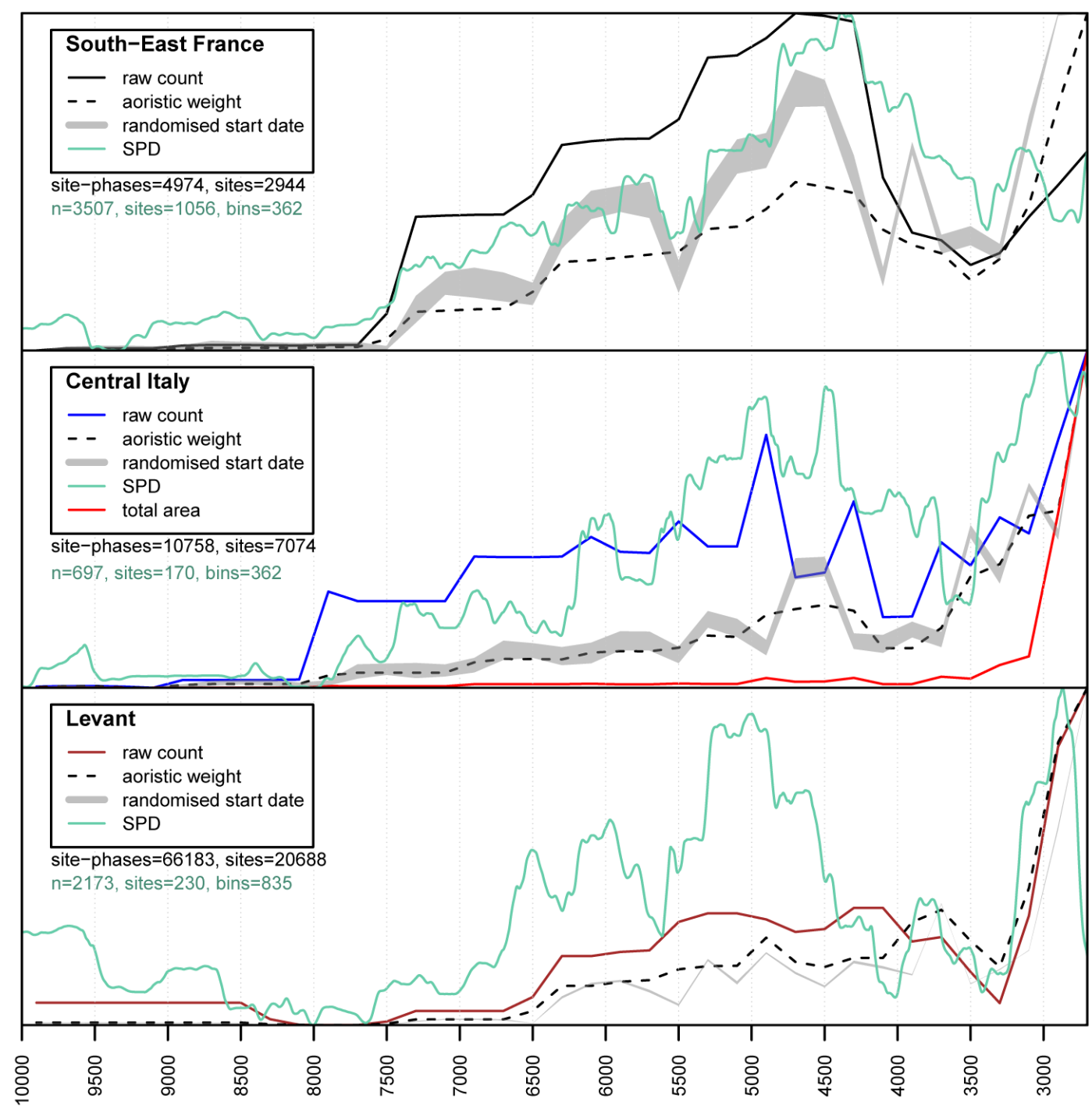


Figure 4: Holocene changes in pollen-inferred land cover in different Mediterranean regions; a) tree cover (\%Arboreal Pollen); b) OJCV pollen (Olea, Juglans, Castanea, Vitis). For France, sub-region 1=Eu-Mediterranean, sub-region 2=Oro-Mediterranean, sub-region 3=mid-Rhône; for Iberia, sub-region 1=northeast Iberia, sub-region 2=southeast Iberia, subregion 3=Balearic Islands; for Greece, sub-region 1=northern Greece, sub-region 2=southern Greece.

Figure 5: a) relationship between early-mid forest cover vs correlation between population and forest decline in different regions; b) population vs climate in northern and southern Greece and in c) central Italy
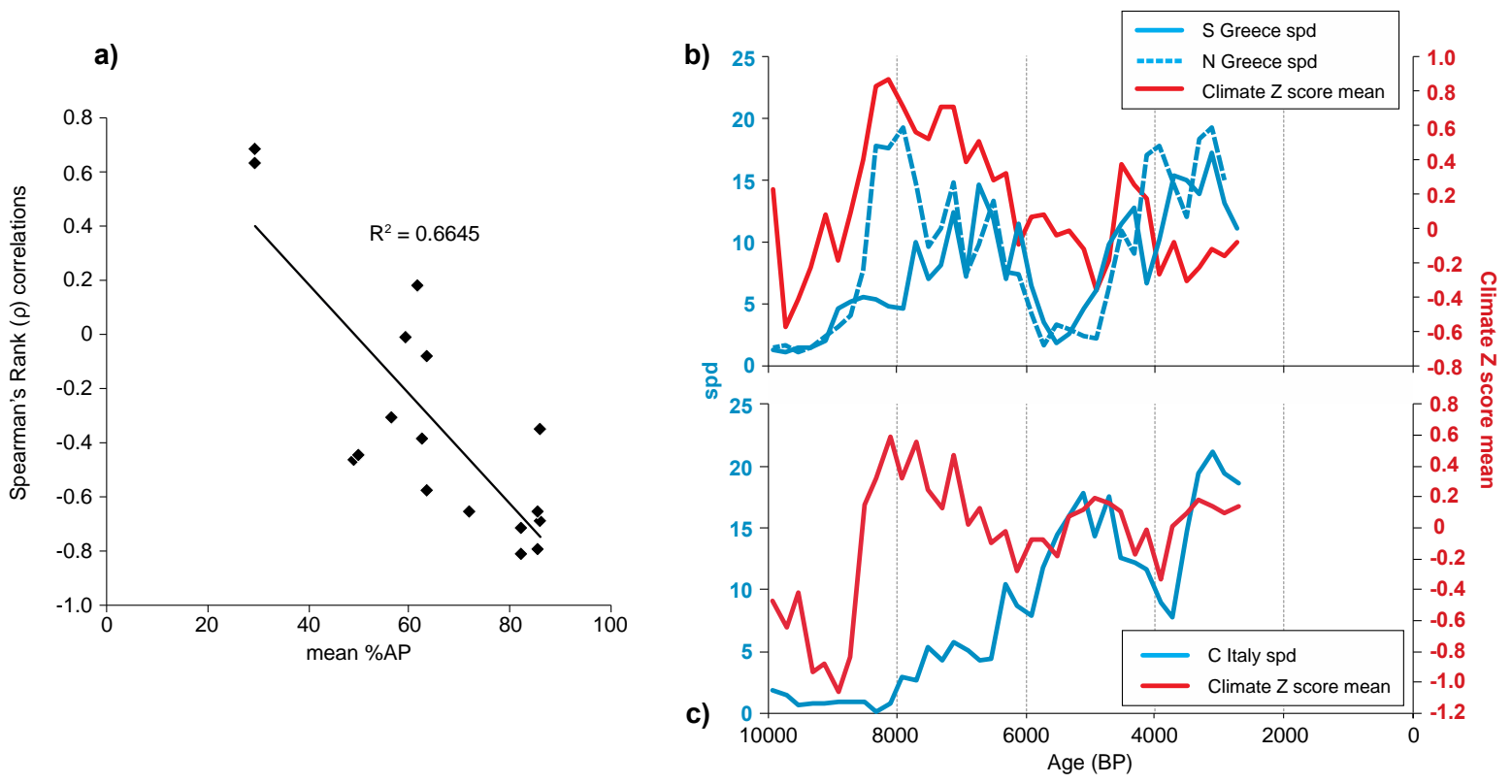
Figure 6: OJCV (Olea, Juglans, Castanea, Vitis) index vs climate z-scores for southern Greece, Anatolia and Levant

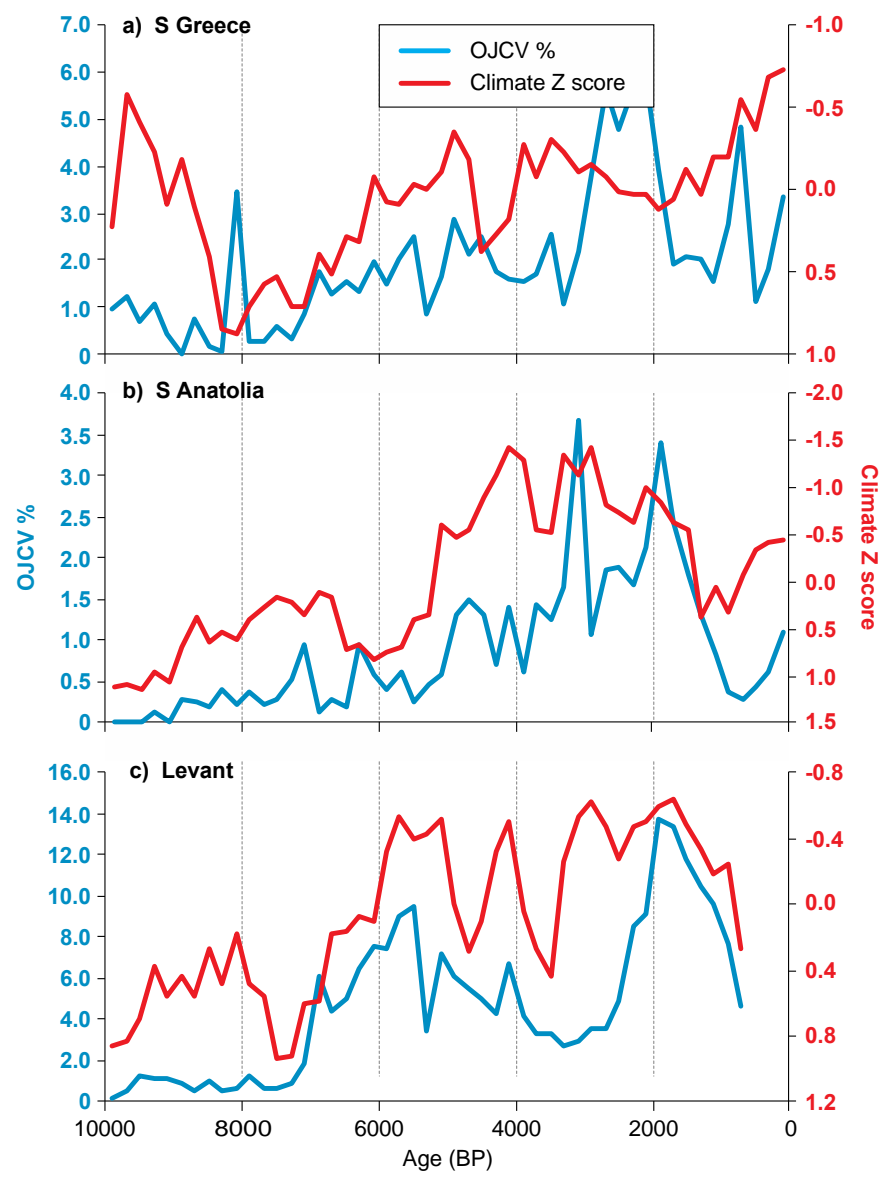


Figure 7: Mediterranean landscape change illustrated by stacked Mediterranean hydroclimate z scores (data from Finné et al., 2019), pollen-inferred land cover cluster rate of change, and open and human-modified classes (data from Woodbridge et al. 2018), average percentage arboreal pollen (\% AP), and regional archaeo-demographic trends from site survey data. The final column shows the changing proportion of circum-Mediterranean land area occupied by farming economies and complex societies (viz. urban, literate)(data taken from maps in Broodbank, 2013).

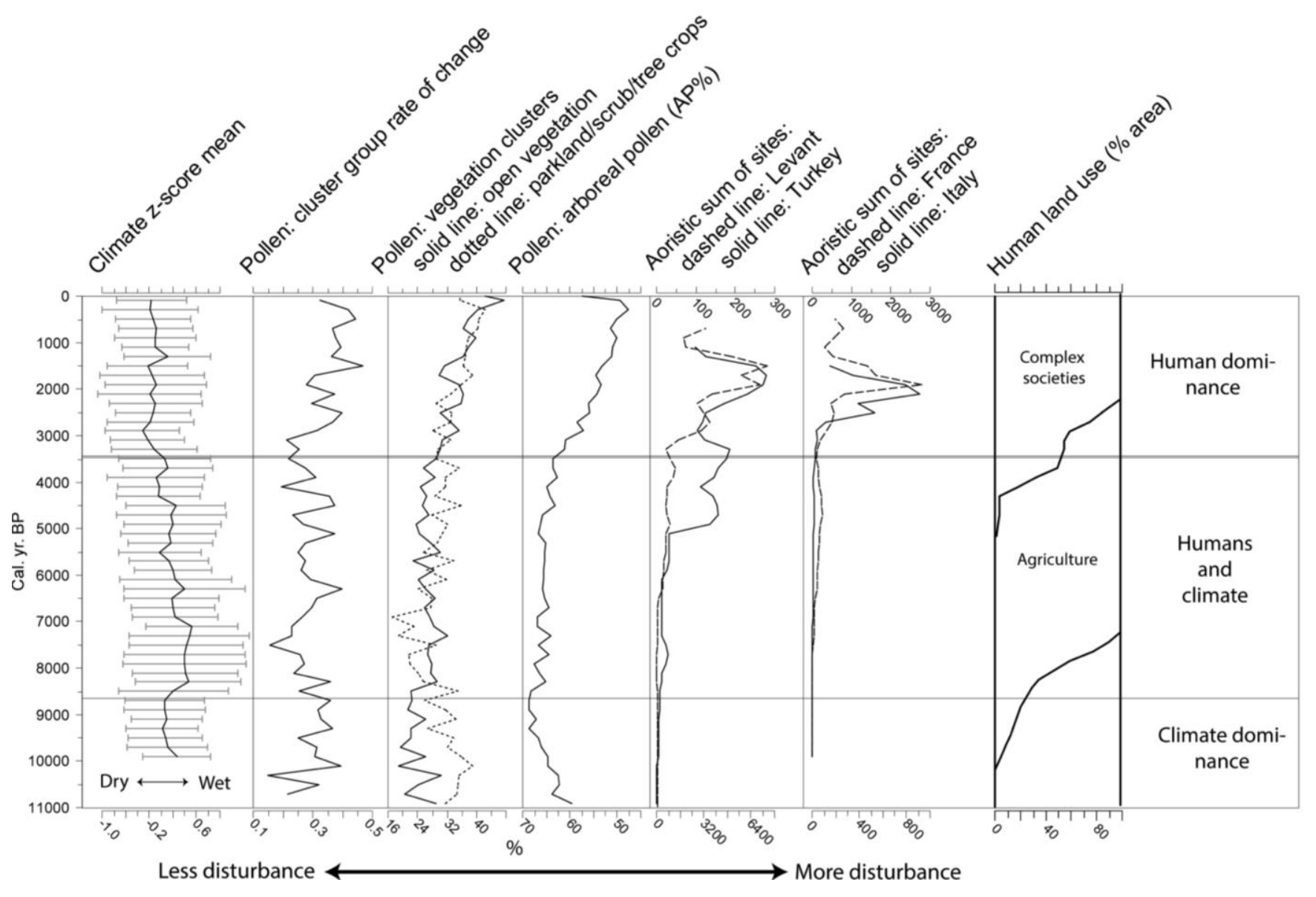


Table 1: Summary of pollen and archaeological data sources synthesized for each case study region. Numbers in brackets represent numbers of ${ }^{14} \mathrm{C}$ dates or archaeological sites used.

\begin{tabular}{|c|c|c|c|c|c|}
\hline Region & $\begin{array}{l}{ }^{14} \mathrm{C} \text { date } \\
\text { Summed } \\
\text { Probability } \\
\text { Density }\end{array}$ & $\begin{array}{c}\text { Site } \\
\text { numbers }\end{array}$ & $\begin{array}{l}\text { Site } \\
\text { areas }\end{array}$ & $\begin{array}{l}\text { Fossil } \\
\text { pollen } \\
\text { sites }\end{array}$ & $\begin{array}{l}\text { Sub-regional } \\
\text { divisions }\end{array}$ \\
\hline $\begin{array}{l}\text { Eastern } \\
\text { Spain }\end{array}$ & YES $(3,885)$ & NO & NO & 30 & $\begin{array}{l}\text { 1. Northeast Iberia } \\
\text { 2. Southeast Iberia } \\
\text { 3. Balearic islands }\end{array}$ \\
\hline $\begin{array}{l}\text { Southern } \\
\text { France }\end{array}$ & YES $(3,507)$ & $\begin{array}{c}\text { YES } \\
(2,944)\end{array}$ & NO & 46 & $\begin{array}{l}\text { 1. Eu-Mediterranean } \\
\text { 2. Oro-Mediterranean } \\
\text { 3. Mid-Rhône }\end{array}$ \\
\hline $\begin{array}{l}\text { Central } \\
\text { Italy }\end{array}$ & YES (697) & $\begin{array}{c}\text { YES } \\
(7,074)\end{array}$ & YES & 13 & na \\
\hline Greece & YES $(2,143)$ & $\begin{array}{c}\text { only for } \\
\text { selected } \\
\text { sub-regions } \\
(1,160)\end{array}$ & $\begin{array}{l}\text { only for } \\
\text { selected } \\
\text { sub- } \\
\text { regions }\end{array}$ & 33 & $\begin{array}{l}\text { 1. Northern Greece } \\
\text { 2. Southern Greece }\end{array}$ \\
\hline $\begin{array}{l}\text { Southern } \\
\text { Turkey }\end{array}$ & $\begin{array}{c}\text { only before } 6 \\
\text { ka BP }(608)\end{array}$ & $\begin{array}{c}\text { YES } \\
(1,426)\end{array}$ & YES & 21 & na \\
\hline Levant & YES $(2,173)$ & $\begin{array}{c}\text { YES } \\
(20,688)\end{array}$ & NO & 14 & na \\
\hline Morocco & YES (270) & NO & NO & 22 & $\begin{array}{l}\text { 1. Atlas mountains } \\
\text { 2. Rif mountains } \\
\text { 3. Lowlands }\end{array}$ \\
\hline
\end{tabular}


Table 2: Mean Arboreal Pollen (AP)\% for different regions and sub-regions, prior to major human land cover conversion (10,000 - 4000 Cal yr BP)

$\begin{array}{lc}\text { Region } & \text { mean \%AP } \\ \text { France (Oro-Med) } & 86.31 \\ \text { France (mid-Rhone) } & 85.84 \\ \text { North Central Italy } & 82.14 \\ \text { Northeast Spain } & 72.11 \\ \text { France (Eu-Med) } & 63.75 \\ \text { N Greece } & 62.51 \\ \text { Morocco } & 61.57 \\ \text { Southeast Spain } & 59.21 \\ \text { S Greece } & 56.63 \\ \text { Balearics } & 50.20 \\ \text { Southern Anatolia } & 48.88 \\ \text { Levant } & 29.41\end{array}$


Table 3: Spearman's Rank cross-correlation coefficients between anthropogenic pollen indicators, archaeo-demographic proxies and climate z-scores for individual regions and sub-regions. Statistically significant correlations at $p=0.05$ are highlighted, with colours indicating expected and reverse relationships. Correlations with climate $z$ scores for the Levant cover start at 9.9 , not at 10.9 ka BP.

\section{Region}

a) ${ }^{14}$ C SPD

Levant

S Greece

$N$ Greece

C Italy

France (Eu-Med)

France (Oro-Med)

France (mid-Rhone)

Balearics

NE Spain

SE Spain

Morocco

\section{b) Aorist weight}

Levant

S Greece

N Greece

$S$ Anatolia

C Italy

France (Eu Med)

France (Oro-Med)

France (mid-Rhone)

c) climate z-score

Levant
S Greece
S Greece
S Anatolia
C Italy
Morocco

Time

period

ka BP

10.9-2.7

9.9-2.9

9.9-2.9

9.9-2.9

9.9-2.7

9.9-2.7

9.9-2.7

9.9-2.5

9.9-2.5

9.9-2.5

9.9-3.1

10.9-0.7

8.7-1.5

8.7-1.7

9.9-1.1

9.9-1.5

9.9-0.7

9.9-0.7

9.9-0.7

9.9-0.1

9.9-0.1

9.9-0.1

9.9-0.1

9.9-0.1

8.9-2.5

\subsection{4}

0.06

$-0.47$

$-0.50$

$-0.81$

$-0.57$

$-0.69$

$-0.79$

$-0.57$

0.21

0.23

0.41

0.01

0.63
0.78

0.67

0.80

0.86

0.58

0.67

0.81

0.82

$-0.72$

$-0.32$

$-0.40$

$-0.78$

0.28

0.57
$-0.46$

0.19

0.34

0.58

0.35

$-0.23$

0.56

0.03

0.32

$-0.15$

nd

$-0.07$

0.35

0.27

0.47

0.70

0.58

0.35

0.75

0.30

$-0.30$

$-0.03$

$-0.49$

0.01

nd



$\begin{array}{ll}-0.47 & -0.64\end{array}$

$0.26 \quad 0.08$

0.05

0.38

0.63

0.16

0.26

0.62

nd

nd

nd

$-0.03$

$-0.42$

0.49

$-0.75$

$-0.62$

$-0.27$

$-0.44$

0.24

$-0.81$

$\mathbf{0 . 7 0} \quad 0.26$

$\mathbf{0 . 5 4}$ nd

0.42

0.72

nd

nd 